\title{
Usefulness of heterologous microsatellites obtained from Genypterus blacodes (Schneider 1801) in species Genypterus off the Southeast Pacific
}

\author{
Utilidad de microsatélites heterólogos de Genypterus blacodes (Schneider 1801) en \\ especies de Genypterus del Pacífico suroriental
}

\author{
Cristian B. Canales-Aguirre ${ }^{1,2^{*}}$, Sandra Ferrada ${ }^{1,2}$, Cristián E. Hernández $^{2}$ \& Ricardo \\ GALLEGUILLOS $^{1}$
}
${ }^{1}$ Laboratorio de Genética y Acuicultura, Departamento de Oceanografía, Universidad de Concepción, Casilla 160-C Concepción, Chile.
${ }^{2}$ Laboratorio de Diversidad Molecular y Filoinformática, Departamento de Zoología, Universidad de Concepción, Casilla $160-$ C Concepción, Chile.
*E-mail: cristiancanales@udec.cl

\section{RESUMEN}

Analizamos la utilidad de cinco loci de microsatélites aislados en Genypterus blacodes de Australia en especies de Genypterus presentes en Chile (G. chilensis, G. maculatus y G. blacodes). Los resultados muestran que los loci microsatélites amplifican positivamente en cada especie y podrían ser utilizados en futuros estudios poblacionales.

\begin{abstract}
Microsatellites are currently one of the most popular and most used genetic markers in molecular ecology (Barbará et al. 2007). These markers are especially useful for evaluating patterns of populations genetic variability, and the microevolutionary mechanisms behind these patterns (e.g. Mundy et al. 1997). One strategy used to obtain microsatellite loci is the construction of a genomic library. Although cloning microsatellite loci for any taxon is relatively simple (Zane et al. 2002), the development of microsatellites still requires deep knowledge experts on molecular biology and a considerable amount of time and resources. An alternative strategy is to test primers described for microsatellite loci in closely related species (that is, cross-priming strategy or heterologous microsatellites). This cross-species amplification is only effective if the flanking regions of the primers are conserved among species. For example, highly conserved flanking regions have been reported in cetaceans (Schlötterer et al. 1991), turtles (FitzSimmons et al. 1995), and fish (Angers \& Bernatchez 1996, Rico et al. 1996). A potentially useful application of cross-species amplification of microsatellites could be its use with species of congeneric commercial importance fishes.
\end{abstract}

Within the order Ophidiiformes, Genypterus is the genus with the largest number of species of economic importance (Nielsen et al. 1999). In the southeast Pacific Ocean three species of the genus can be found: G. chilensis, G. maculatus, and $G$. blacodes; and despite their importance, there are few genetic studies on Genypterus species.

There are no existing genetic studies regarding $G$. chilensis, and only one in relation to G. maculatus through allozymes
(Alay et al. 1993). There are a few studies involving $G$. blacodes (although not from the southeast Pacific), two of these studies used allozymes (Smith 1979, Smith \& Francis 1982), and two other studies use microsatellite loci (Ward \& Reilly 2001, Ward et al. 2001). The lack of genetic studies regarding these species could result in inadequate measures of fishery management policies.

The availability of microsatellite loci isolated from $G$. blacodes from Australia could contribute to population studies regarding species of the genus off the southeast Pacific. Therefore, the objective of the present study is to determine the usefulness of these markers in G. chilensis, $G$. maculatus and G. blacodes from the southeast Pacific.

We tested five pairs of microsatellite primers previously isolated from $G$. blacodes in Australia (Ward \& Reilly 2001: cmrGb4.2A, cmrGb4.2B, cmrGb4.11B, cmrGb5.2B, and cmrGb5.9) on six G. blacodes (from the southeast Pacific), five $G$. chilensis and seven $G$. maculatus individuals. DNA was extracted from muscle tissue samples according to the protocol described by Grijalva-Chon et al. (1994). The quantity and quality DNA was measured by an Eppendorf ${ }^{\circledR}$ BioPhotometer and the DNA was diluted to $20 \mathrm{ng}$ for amplifications. The PCR conditions for each locus were applied as described by Ward et al. (2001). The PCR products were separated by means of electrophoresis in $6 \%$ polyacrylamide gel and were visualized with silver staining (Acrylamide:BisAcrylamide Kit; Winkler ${ }^{\circledR}$ ). A 10 pb marker (Invitrogen, Life Technologies, USA) was used as a standard weight marker to evaluate the size of the amplified products. 
The genotypes were identified using the LabWork ${ }^{\mathrm{TM}}$ v4.6.00.0 software (UVP®, Inc.), which estimates the size of alleles based on electrophoretic mobility in relation to the mobility of the weight marker. Deviations from Hardy-Weinberg equilibrium between markers were tested using Arlequin v3.0 (Excoffier et al. 2005). The Genetix v4.05 program (Belkhir et al. 2000) was used to conduct a Factorial Correspondence Analysis (FCA). With this approach, we evaluated the usefulness of these markers in species differentiation. Additionally, a dendrogram was generated based on the Nei's standard genetic distance (Ds), using the UPGMA clustering method in the TFPGA v1.3 program (Miller 1997).

The results showed positive amplification of microsatellite loci in the three species. The percentage of amplification, mean number of alleles and size range of each locus varied between species (Table 1). Three loci showed significant deviation from Hardy-Weinberg equilibrium (Table 1). The percentage of variation in the FCA (Fig. 1) was explained by the first two axes (Axis1: 51.45; Axis2: 48.55). With these results, $G$. blacodes can be differentiated from other species. The dendrogram constructed by means of UPGMA corroborates these results (Fig. 2). The most closely related species are G. chilensis and G. maculatus, and G. blacodes appears as sister group of both species.
Our results confirm that flanking regions of microsatellite loci have been conserved in closely related species of the genus Genypterus, as observed in other studies with congeneric species or other taxonomic groups (Schlötterer et al. 1991, FitzSimmons et al. 1995, Angers \& Bernatchez 1996, Rico et al. 1996). The percentage of amplification (Table 1) does not indicate a great loss of diversity among species $(83.3 \%$ for $G$. blacodes, $88 \%$ for G. chilensis, and $97.1 \%$ for $G$. maculatus positive amplification), considering that a percentage of $57.2 \%$ and $57.3 \%$ of polymorphism and amplification, respectively, has been described for fish species (Barbará et al. 2007). However, given the low number of analyzed samples, these results should be taken with precaution. Our observations differ from other studies, in which a decrease in genetic diversity between species has been observed when using heterologous microsatellites (Primmer \& Merilä 2002). The presence of null alleles could reduce genetic variability with increasing phylogenetic distance from a focal species (e.g. in the oyster Crassostrea, Li et al. 2003). Particularly among fish, the decrease of genetic variability is greater between genera of the same family, than between species of the same genus (Barbará et al. 2007), in conformity with the results obtained here.

TABLE 1: Loci microsatellite used to evaluate interspecific amplification. N: number of individuals; Na: number of alleles. Values in bold show significant deviation from Hardy-Weinberg equilibrium $(\mathrm{P} \leq 0.05)$.

TABLA 1: Marcadores microsatélites usados para evaluar amplificación interespecífica. N: número de individuos; Na: número de alelos. Los valores en negrita muestran desviación significativa de equilibrio de Hardy-Weinberg $(\mathrm{P} \leq 0,05)$.

\begin{tabular}{|c|c|c|c|c|c|c|c|c|}
\hline & $\mathrm{N}$ & Parameter & cmrGb4.2A & cmrGb4.2B & cmrGb4.11B & cmrGb5.2B & cmrGb5.9 & Mean \\
\hline \multirow[t]{4}{*}{ G. blacodes } & 6 & $\%$ Amplification & 66.6 & 100 & 66.6 & 83.3 & 100 & 83.3 \\
\hline & & $\mathrm{Na}$ & 2 & 8 & 6 & 6 & 7 & 5.8 \\
\hline & & Range & $174-206$ & $161-183$ & $199-246$ & $114-154$ & $146-168$ & - \\
\hline & & H\&W (p-value) & 0.671 & 1.000 & 0.809 & 0.683 & 1.000 & \\
\hline \multirow[t]{4}{*}{ G. chilensis } & 5 & $\%$ Amplification & 60 & 80 & 100 & 100 & 100 & 88 \\
\hline & & $\mathrm{Na}$ & 5 & 7 & 4 & 6 & 5 & 5.4 \\
\hline & & Range & $202-246$ & $147-190$ & $210-216$ & $126-166$ & $130-156$ & - \\
\hline & & H\&W (p-value) & 1.000 & 0.003 & 0.162 & 0.282 & 0.197 & \\
\hline \multirow[t]{4}{*}{ G. maculatus } & 7 & $\%$ Amplification & 85.7 & 100 & 100 & 100 & 100 & 97.1 \\
\hline & & $\mathrm{Na}$ & 7 & 8 & 8 & 7 & 6 & 7.2 \\
\hline & & Range & $186-238$ & $155-185$ & $202-234$ & $126-154$ & $136-162$ & - \\
\hline & & H\&W (p-value) & 0.003 & 0.864 & 0.415 & 0.045 & 0.163 & \\
\hline
\end{tabular}


The positive amplification of heterologous microsatellites in species of Genypterus from the southeast Pacific indicates that these could be used to test polymorphism in other species of Genypterus spp., such as G. brasiliensis (southeast Atlantic), G. capensis (south of Africa) and $G$. tigerinus (Australia). Finally, five of the microsatellite loci isolated from G. blacodes from Australia (Ward \& Reilly 2001) proved to be useful for genetic studies of congeneric species.

G. blacodes

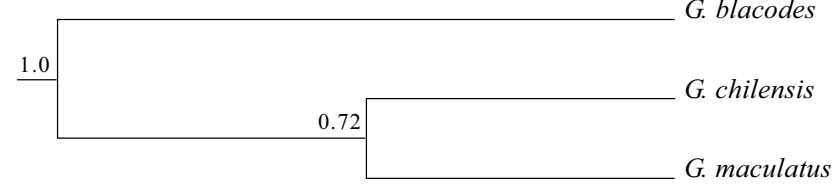

Figure 1: Factorial Correspondence Analysis (FCA) between species of the genus Genypterus of the southeast Pacific.

Figura 1: Análisis Factorial de Correspondencia (AFC) entre las especies del género Genypterus del Pacífico sureste.

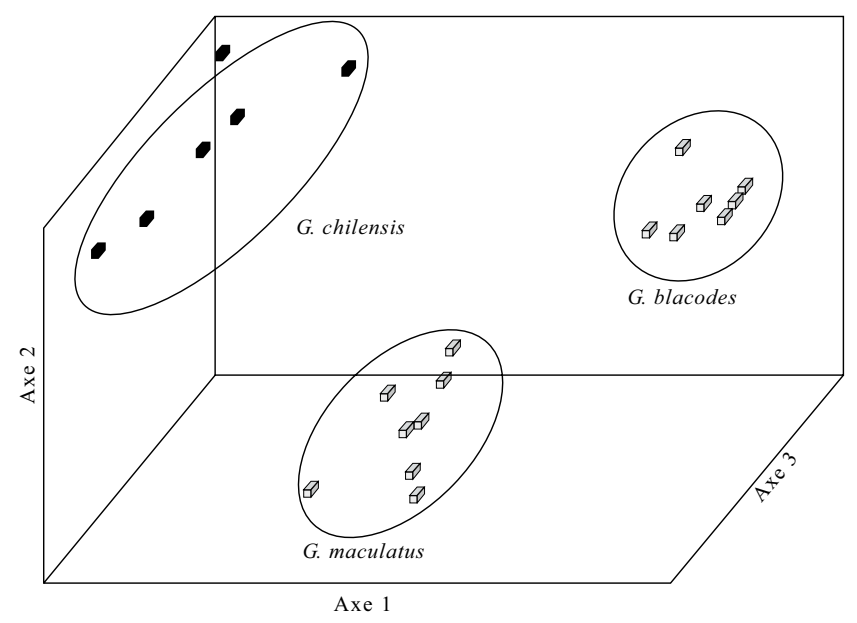

FIGURE 2: Dendrogram based on Nei's standard genetic distance using UPGMA. Values above branches depict the bootstrap support values.

FIGURA 2: Dendrograma basado en la distancia genética estándar de Nei usando UPGMA. Los valores sobre las ramas representan los valores de soporte de bootstrap.

\section{ACKNOWLEDGMENTS}

Both C.B. Canales-Aguirre and S. Ferrada belong the doctoral program in systematic and biodiversity and both were supported by UdeC posgraduate Fellowships. We thank two anonymous referees for useful suggestions.

\section{REFERENCES}

Alay, F., F. GonzÁlez \& J. Cabello. 1993. Variabilidad genética en Genypterus maculatus (Tschudi, 1846) (Pisces, Ophidiformes). Revista de Biología Marina 28: 301-312.

Angers, B. \& L. Bernatchez. 1996. Usefulness of heterologous microsatellites obtained from brook charr, Salvelinus fontinalis Mitchill, in other Salvelinus species. Molecular Ecology 5: 317-319.

Barbará, T., C. Palma-Silva, G.M. Paggi, F. Bered, M.F. Fay \& C. LEXER. 2007. Cross-species transfer of nuclear microsatellite markers: potential and limitations. Molecular Ecology 16 3759-3767.

Belkhir, K., P. Borsa \& L. ChiKhI. 2000. GENETIX 4.05, logiciel sous Windows TM pour la génétique des populations. Laboratoire Génome, Populations, Interactions, CNRS UMR 5000. Université de Montpellier II, Montpellier.

EXCOFFIER, L., G. LAVAL, \& S. SCHNEIDER. 2005. Arlequin ver. 3.0: An integrated software package for population genetics data analysis. Evolutionary Bioinformatics Online 1: 47-50.

FitzSimmons, N.N., C. Moritz \& S.S. Moore. 1995. Conservation and dynamics of microsatellite loci over 300 million years of marine turtle evolution. Molecular Biology and Evolution 12: 432-440.

Grijalva-Chon, J., J. Kumachi, K. Sosa-Nishizaki \& J. DE la RosaVÉLEz. 1994. Mitochondrial DNA analysis of North Pacific swordfish Xiphias gladius population structure. Marine Ecology Progress Series 115: 15-19.

Li, G., S. Hubert, K.bucklin, V. Ribes \& D. Hedgecock. 2003. Characterization of 79 microsatellite DNA markers in the Pacific oyster Crassostrea gigas. Molecular Ecology Notes 3: $228-232$

MiLLER, M.P. 1997. Tools for population genetics analyses (TFPGA): a Windows program for the analysis of allozyme and molecular population genetic data. http://herb.bio.nau. edul miller/tfpga.htm.

Mundy, N.I., C.S. Winchell, T. BurR \& D.S. WoodrufF. 1997. Microsatellite variation and microevolution in the critically endangered San Clemente Island loggerhead shrike (Lanius ludovicianus mearnsi). Proceedings of the Royal Society London Series B 264: 869-875.

Nielsen, J.G., D.M. Cohen, D.F. Markle \& C.R. Robins. 1999. Ophidiiform Fishes of the World (Order Ophidiiformes), Vol. 18. Rome: Food and Agriculture Organization of the United Nations (FAO).

Primmer, C.R. \& J. Merilä. 2002. A low rate of cross-species microsatellite amplification success in ranid frogs. Conservation Genetics 3: 445-449.

Rico, C., I. Rico \& G. HewitT. 1996. 470 million years of conservation of microsatellite loci among fish species. Proceedings of the Royal Society London Series B 263: 549-557. 
Schlötterer, C., B. Amos \& D. Tautz. 1991. Conservation of polymorphic simple sequence loci in cetacean species. Nature 354: 63-65.

SMith, P. 1979. Glucosephosphate isomerase and phosphoglucomutase polymorphisms in the New Zealand king Genypterus blacodes. Comparative Biochemistry and Physiology 62B: 135-163.

Smith, P. \& R. Francis. 1982. A glucosephosphate isomerase polymorphism in New Zealand king Genypterus blacodes. Comparative Biochemistry and Physiology 73B: 451-455.

Ward, R. \& A. ReILly. 2001. Development of microsatellite loci for population studies of the pink ling, Genypterus blacodes (Teleostei: Ophidiidae). Molecular Ecology Notes 1: 173-175.

Ward, R., S.A. Appleyard, R.K. Daley \& A. Reilly. 2001. Population structure of pink ling (Genypterus blacodes) from south-eastern Australian waters, inferred from allozyme and microsatellite analyses. Marine and Freshwater Research 52: 965-973.

Zane, L., L. Bargelloni \& T. Patarnello. 2002. Strategies for microsatellite isolation: A review. Molecular Ecology 11: $1-16$. 